\title{
HUBUNGAN PERAWATAN TALI PUSAT MENGGUNAKAN KASSA KERING STERIL SESUAI STANDAR DENGAN LAMA PELEPASAN TALI PUSAT PADA BAYI BARU LAHIR DI PUSKESMAS SIANTAN HILIR TAHUN 2019
}

\author{
Elise Putri ${ }^{1}$, Megalina Limoy ${ }^{2}$
}

\author{
Akademi Kebidanan Panca Bhakti Pontianak \\ Email korespondensi : akbidpbpontianak@gmail.com
}

\begin{abstract}
Abstrak
Salah satu indikator derajat kesehatan di Indonesia adalah angka kematian bayi. World Health Organization pada Tahun 2016 menemukan angka kematian bayi sebesar 560.000 dari kelahiran hidup yang disebabkan oleh infeksi tali pusat. Infeksi tali pusat dapat terjadi dikarenakan perawatan tali pusat yang tidak sesuai standar. Sejumlah 39\% ibu tidak melakukan perawatan tali pusat sesuai standar yaitu menggunakan kassa kering steril di wilayah kerja Puskesmas Siantan Hilir tahun 2019. Tujuan penelitian ini untuk mengetahui hubungan perawatan tali pusat menggunakan kassa kering steril sesuai standar terhadap lama pelepasan tali pusat bayi baru lahir. Desain penelitian yang digunakan adalah Deskriptif korelasi dengan analisa data Chi Square. Populasi yang diteliti 154 bayi. Pengambilan sampel dengan random sampling jumlah sampel 31 bayi. Hasil penelitian menunjukkan dari hasil analisa data dengan Chi Square didapatkan hasil $P$-value $0,022<\alpha 0,05$ maka $\mathrm{H}_{0}$ tolak $\mathrm{H}_{\mathrm{a}}$ diterima. Kesimpulan dalam penelitian ini adalah terdapat hubungan perawatan tali pusat menggunakan kassa kering steril sesuai standar dengan lama pelepasan tali pusat pada bayi baru lahir. Saran kepada pihak puskesmas untuk tetap memberikan informasi tentang perawatan tali pusat sesuai standar yaitu dengan kassa kering steril karena dapat dilihat dari hasil penelitian bahwa kassa kering steril sesuai standar efektif untuk melakukan perawatan tali pusat.
\end{abstract}

Kata kunci: Perawatan Tali Pusat, Kassa Kering Steril, BBL

\section{Pendahuluan}

Salah satu program pembangunan

kesehatan di Indonesia pada periode 2015-2019 adalah meningkatkan status kesehatan gizi ibu dan anak di Indonesia. Kesehatan merupakan modal utama dalam pembentukan generasi yang kuat, berkualitas dan produktif. Masalah kesehatan anak merupakan salah satu masalah utama dibidang kesehatan yang saat ini terjadi di negara Indonesia. Derajat kesehatan anak mencerminkan derajat kesehatan bangsa, sebab anak sebagai generasi penerus bangsa memiliki kemampuan yang dapat dikembangkan dalam meneruskan pembangunan bangsa (Hartono, 2015).

\footnotetext{
${ }^{1}$ Dosen Akademi Kebidanan Panca Bhakti Pontianak

${ }^{2}$ Dosen Akademi Kebidanan Panca Bhakti Pontianak
}

Tali pusat dalam istilah medis disebut dengan umbilical cord. Merupakan saluran kehidupan bagi janin selama bayi di dalam kandungan sebab semasa dalam rahim, tali pusat ini yang menyalurkan oksigen dan makanan dari placenta kejanin yang berada didalamnya. Begitu janin dilahirkan, bayi tidak lagi membutuhkan makanan dan oksigen dari ibunya karena bayi sudah dapat bernafas sendiri melalui hidungnya. Karena sudah tidak diperlukan lagi maka saluran ini harus dipotong dan dijepit atau diikat (Wibowo, 2011).

Bayi baru lahir mempunyai resiko terpapar infeksi yang tinggi terutama pada tali 
pusat yang merupakan luka basah dan dapat menjadi pintu masuknya kuman tetanus yang sangat sering menjadi penyebab sepsis dan kematian bayi baru lahir (Ellen, 2014). Salah satu indikator derajat kesehatan di Indonesia adalah angka kematian bayi. Tingginya angka kematian bayi di Indonesia disebabkan oleh berbagai faktor, diantaranya adalah faktor penyakit, infeksi dan kekurangan gizi.

Salah satu ancaman pada bayi adalah terjadinya infeksi tali pusat dikarenakan perawatan tali pusat yang tidak baik dan benar dan adanya ketidaksesuaian dengan Standard Operational Procedure (SOP) yang telah ditentukan. Salah satu upaya yang dapat dilakukan untuk menurunkan angka kematian bayi perlu dilakukan perawatan bayi yang baik dan benar, khususnya perawatan tali pusat agar terhindar dari resiko infeksi yaitu dengan berbagai metode diantaranya perawatan tali pusat menggunakan alkohol $70 \%$, topical ASI dan kassa kering steril (Hidayat, 2011).

Pada umumnya perawatan tali pusat yang benar dan sesuai standar yang ditetapkan diharapkan tidak menyebabkan terjadinya komplikasi pada bayi. Akibat komplikasi yang dapat terjadi yaitu infeksi yang kemudian menjadi tetanus neonatorum dan sepsis dengan berbagai macam perawatan tali pusat, diantaranya menggunakan alkohol $70 \%$, beberapa diantaranya masih menggunakan povidone iodine dan penggunaan kassa kering steril (Paisal, 2013).

World Health Organization (WHO) pada Tahun 2016 menemukan angka kematian bayi sebesar 560.000 dari kelahiran hidup yang disebabkan oleh infeksi tali pusat. Di Asia Tenggara angka kematian bayi karena infeksi tali pusat sebesar 126.000 dari kelahiran hidup. Asiyah (2017), menyatakan angka kejadian infeksi bayi baru lahir di Indonesia berkisar antara $24 \%$ hingga $34 \%$, dan hal ini merupakan penyebab kematian yang kedua setelah asfiksia neonatorum yang berkisar antara 49\% hingga $60 \%$. Sebagian besar infeksi bayi baru lahir adalah tetanus neonatorum, karena pemotongan dengan alat tidak steril, dan dikarenakan perawatan tali pusat yang tidak benar contohnya dengan pemakaian daundaunan yang digunakan masyarakat dalam merawat tali pusat.

Angka Kematian Bayi (AKB) pada tahun 2013 mencapai 23/1000 kelahiran hidup. Dimana $79 \%$ terjadi pada minggu pertama pasca kelahiran. Penyebab kematian neonatal yang tertinggi adalah infeksi neonatorum, yang salah satunya disebabkan karena perawatan tali pusat yang tidak benar. AKB dan AKI adalah salah satu indikator penting dalam menentukan tingkat kesehatan suatu negara. AKI dan AKB menentukan kemampuan dalam menangani kasus dan memahami masalah kesehatan yang sering muncul baik secara maternal dan neonatal (Wiknjosastro, 2011).

Dalam rangka mendukung Sustainable Development Goals (SDGs), 2015 yakni menekan angka kematian bayi mencapai 12 per 1000 angka kelahiran hidup pada tahun 2030, yang salah satunya adalah dengan menekan angka infeksi. Khususnya pada kejadian infeksi tali pusat yaitu sekitar 23\% sampai 91\% tali pusat yang tidak dirawat dengan baik akan 
terinfeksi oleh kuman staphylococcus aureus pada 72 jam pertama setelah kelahiran. Hal ini sangat dipengaruhi perilaku ibu dalam memberikan perawatan tali pusat yang benar dan sesuai dengan standar yang ditentukan (Astutik, 2015).

Dapat dilihat dari data berikut ini bahwa, Angka Kematian Bayi (AKB) Kalimantan Barat untuk tahun 2012 sebesar 31 per 1000 kelahiran hidup. Angka Kematian Ibu (AKI) sebesar 603,15 per 100.000 kelahiran hidup dan penyebab kematian kematian bayi baru lahir adalah sepsis 20,5\%, kelainan kongenital $18,1 \%$, pneumonia $15,4 \%$, prematuritas dan BBLR 12,8\%, dan respiratory disorder 12,8\%.

Penyebab langsung kematian bayi adalah Berat Bayi Lahir Rendah (BBLR) dan kekurangan oksigen (asfiksia). Merujuk pada data profil kesehatan kabupaten atau kota yang masuk di Dinas Kesehatan Provinsi Kalimantan Barat, terlihat bahwa kasus kematian bayi yang dilaporkan pada tahun 2017 sebesar 692 kasus dengan 86.572 kelahiran hidup, sehingga dengan demikian jika dihitung angka kematian bayinya adalah 8 per 1000 kelahiran hidup. Angka kematian bayi terjadi karena beberapa faktor diantaranya asfiksia neonatorum, infeksi neonatorum dan lain-lain (Dinkes Kalbar, 2017).

Salah satu upaya yang dapat dilakukan untuk menurunkan angka kesakitan dan angka kematian bayi adalah dengan memberikan pelayanan kesehatan yang efektif pada masyarakat tentang perawatan tali pusat bayi. Dalam melaksanakan upaya tersebut diperlukan sumber daya manusia yang mempunyai kemampuan untuk memberikan pelayanan yang berkualitas, yaitu dengan memberikan penyuluhan tentang kesehatan kepada masyarakat, sehingga pengetahuan yang dimiliki oleh masyarakat diharapkan dapat mempengaruhi perilaku masyarakat terhadap kesehatan (IDAI, 2011).

Infeksi tali pusat telah menjadi penyebab kesakitan dan kematian secara terus menerus diberbagai negara. Setiap tahunnya 500.000 bayi meninggal karena tetanus neonatorum dan 460.000 bayi meninggal akibat infeksi bakteri. Di wilayah Asia Tenggara diperkirakan ada 220.000 kematian bayi yang disebabkan karena perawatan tali pusat yang kurang bersih. Lama pelepasan tali pusat pada bayi dengan perawatan kering tertutup lebih cepat $(70.105$ jam) selisih waktu 35 jam dibandingkan dengan perawatan dengan alkohol. Hasil penelitian yang dilakukan oleh Sri Sumaryani yang dilakukan pada tahun 2013 menunjukkan rata waktu pelepasan tali pusat yang dirawat dengan alkohol 70\% 6,87 hari/165 jam, kassa kering membutuhkan waktu 6,65 hari/159 jam, dan dengan menggunakan ASI membutuhkan waktu 5,32 hari/127 jam (Kasiati, 2015).

Tali pusat pada neonatus merupakan salah satu reservoir kuman yang dapat menimbulkan infeksi, bahkan menjadi sumber penularan. Untuk itu perlu pengetahuan tentang perawatan tali pusat yang benar. Infeksi tali pusat dapat dihindari dengan tindakan aseptis dengan menggunakan zat antiseptik, alkohol $70 \%$ atau povidone-iodine $10 \%$ dan dengan menggunakan kassa kering steril. Sampai sekarang masih terdapat perbedaan pendapat 
mengenai pencegahan infeksi tali pusat dan belum diketahui perlakuan mana yang paling baik dalam mencegah infeksi tali pusat dan yang paling cepat menyebabkan terjadinya pelepasan tali pusat (Sodikin, 2013).

Didalam proses perawatan tali pusat terdapat beberapa metode yang dapat digunakan salah satunya menggunakan antiseptik. Antiseptik digunakan adalah antiseptik yang dapat menghambat pertumbuhan dan merusak sel-sel bakteri, spora bakteri jamur, virus dan protozoa, tanpa merusak jaringan tubuh. Antiseptik dapat merusak sel dengan cara koagulasi atau denaturasi protein protoplasma sel atau menyebabkan sel mengalami lisis, yaitu dengan mengubah membran sel sehingga menyebabkan kebocoran inti sel. Terdapat beberapa golongan antiseptik yang dapat digunakan untuk melakukan perawatan tali pusat diantaranya adalah alkohol dan betadine (Paisal, 2013).

Segala macam bentuk infeksi merupakan hal yang menakutkan bagi ibu yang memiliki bayi baru lahir. Tali pusat juga tidak luput menjadi tempat berkembangnya kuman penyakit. Penyebaran kuman ini disebabkan oleh gerak tubuh bayi. Ada beberapa cara untuk mencegah terjadinya infeksi pada tali pusat yang paling umum dilakukan adalah tindakan aseptis, yaitu menggunakan zat antiseptik yaitu alkohol $70 \%$ dan menutup pusar dengan bahan steril yaitu kassa steril (Paisal, 2013).

Tujuan dari perawatan tali pusat adalah untuk mencegah terjadinya infeksi pada bayi baru lahir, agar tali pusat tetap bersih, kumankuman dan bakteri tidak masuk sehingga infeksi tali pusat pada bayi dapat dicegah. Infeksi tali pusat tergolong jenis infeksi ringan akan tetapi jika tidak di tangani dengan baik maka dapat berkembang menjadi infeksi yang membahayakan dan bahkan dapat menjadi salah satu penyebab kematian Bayi Baru Lahir (BBL) (Saifuddin, 2014).

Berdasarkan hasil studi pendahuluan yang di lakukan oleh peneliti di Puskesmas Siantan Hilir diperoleh hasil dari data 2 bulan terakhir diperoleh 36 ibu melahirkan dan masing-masing ibu memiliki cara yang berbeda dalam merawat tali pusat bayinya. Hasil wawancara yang dilakukan diperoleh hasil bahwa $12(33,33 \%)$, ibu melahirkan merawat tali pusat bayinya menggunakan betadine dan 6 (25\%) orang ibu melahirkan memilih menggunakan bubuk-bubuk herbal dari bahan kunyit, kapur dan dedaunan. 4 (11,11\%) orang ibu melahirkan merawat tali pusat mengunakan alkohol.

Beberapa ibu 14 (39\%) orang menceritakan bahwa tali pusat bayinya mengalami infeksi sebelum terlepas seperti berbau tidak sedap dan mengeluarkan air dan tali pusat bayinya cenderung lama terlepas kisaran waktu untuk pelepasan tali pusat yaitu 7-9 hari. 5 orang ibu yang bayinya mengalami infeksi tali pusat merawat tali pusat bayinya menggunakan bubuk kunyit, kapur sirih dan 9 orang bayi yang mengalami infeksi tali pusat karena diberikan perawatan betadine dan alkohol $70 \%$. Hal ini dapat terjadi dikarenakan para ibu tidak merawat tali pusat bayinya dengan baik dan benar serta tidak sesuai dengan standar yang ditentukan. Kassa kering steril 
didalam beberapa penelitian memiliki manfaat melindungi tali pusat dari paparan bakteri dan dapat mempercepat penyembuhan luka selain itu kassa kering steril tergolong ekonomis dan praktis tanpa harus mengeluarkan biaya yang besar untuk merawat tali pusat bayi.

Berdasarkan data diatas peneliti tertarik untuk mengambil judul karya tulis ilmiah "Hubungan Perawatan Tali Pusat Menggunakan Kassa Kering Steril sesuai Standar dengan Lama Pelepasan Tali Pusat Pada Bayi Baru Lahir di Puskesmas Siantan Hilir Tahun 2019". Dikarenakan masih tingginya angka infeksi yang terjadi dan berpengaruh pada pelepasan tali pusat pada bayi baru lahir. Hal ini dapat terjadi karena tidak melakukan perawatan tali pusat yang sesuai dengan SOP yang ada.

\section{Metode Penelitian}

Jenis penelitian yang digunakan dalam penelitian ini adalah Deskriptif korelasi yaitu penelitian yang dilakukan untuk menggambarkan hubungan antara dua variable yaitu variable perawatan tali pusat menggunakan kassa steril sesuai standar dengan variable lama pelepasan tali pusat yang akan diobservasi pada bayi baru lahir di puskesmas siantan hilir kota Pontianak utara tahun 2019. Analisa data yang digunakan adalah Chi Square. Populasi yang diteliti sejumlah 154 bayi. Pengambilan sampel dengan random sampling dengan jumlah sampel 31 bayi.

\section{Hasil dan Pembahasan}

Tabel 1. Karakteristik Variabel di Puskesmas Siantan Hilir Tahun 2019

\begin{tabular}{lcc}
\hline \multicolumn{1}{c}{ Karakteristik } & Frekuensi & Persentase (\%) \\
\hline Perawatan Tali Pusat Menggunakan Kassa Kering & & \\
Steril & & \\
$\quad$ Tidak Sesuai Standar & 8 & 25,8 \\
$\quad$ Sesuai Standar & 23 & 74,2 \\
Lama Pelepasan Tali Pusat & & 25,8 \\
$\quad$ Lambat & 8 & 74,2 \\
$\quad$ Normal & 23 & \\
\hline
\end{tabular}

Berdasarkan tabel 1 diatas, diketahui bahwa lebih banyak ibu di wilayah kerja Puskesmas Siantan Hilir melakukan perawatan tali pusat menggunakan kassa kering steril yang sesuai standar, yaitu sebanyak 23 ibu $(74,2 \%)$ dan sebanyak 23 bayi $(74,2 \%)$ dengan lama pelepasan tali pusat dalam kategori normal.

Tabel 2. Analisis Bivariat

\begin{tabular}{|c|c|c|c|c|c|c|c|}
\hline \multirow{3}{*}{$\begin{array}{c}\text { Perawatan Tali Pusat } \\
\text { Menggunakan Kassa } \\
\text { Kering Steril Sesuai } \\
\text { Standar }\end{array}$} & \multicolumn{4}{|c|}{ Lamanya Pelepasan Tali Pusat } & \multirow{2}{*}{\multicolumn{2}{|c|}{ Total }} & \multirow{3}{*}{$\mathrm{p}$-value } \\
\hline & \multicolumn{2}{|c|}{ Lambat } & \multicolumn{2}{|c|}{ Normal } & & & \\
\hline & $\mathrm{N}$ & $\%$ & $\mathrm{~N}$ & $\%$ & $\mathrm{~N}$ & $\%$ & \\
\hline Tidak Sesuai Standar & 5 & 62,5 & 3 & 37,5 & 8 & 100 & $0 \Omega$ \\
\hline Sesuai Standar & 3 & 13,0 & 20 & 87,0 & 23 & 100 & 022 \\
\hline
\end{tabular}


Berdasarkan tabel 2 diketahui bahwa hampir seluruh responden $20(87,0 \%)$ ibu melakukan perawatan tali pusat menggunakan kassa kering steril sesuai standar dengan lama pelepasan tali pusat dalam kategori normal, sedangkan sebagian besar dari responden 5 $(62,5 \%)$ ibu melakukan perawatan tali pusat menggunakan kassa kering steril tidak sesuai standar dengan lama pelepasan tali pusat dalam kategori lambat. Hasil uji hipotesa chi square diperoleh p-value sebesar $0,022<\alpha 0,05$, maka dapat disimpulkan bahwa ada hubungan perawatan tali pusat menggunakan kassa kering steril sesuai standar terhadap lamanya pelepasan tali pusat bayi di Puskesmas Siantan Hilir tahun 2019.

Perawatan tali pusat adalah proses perbuatan, bagaimana cara merawat, pemeliharaan, penyelenggaraan tali pusat (Sodikin, 2013). Hal yang paling terpenting dalam membersihkan tali pusat adalah memastikan tali pusat dan area disekelilingnya selalu bersih dan kering, selalu mencuci tangan dengan menggunakan air bersih dan sabun sebelum membersihkan tali pusat. Selama tali pusat belum puput atau terlepas, sebaiknya bayi tidak dimandikan dengan cara dicelupkan ke dalam air. Cukup diusap saja dengan kain yang direndam air hangat.

Selain itu salah satu cara untuk menurunkan angka kematian bayi adalah dengan cara melakukan perawatan tali pusat dengan bersih dan benar agar tali pusat cepat terlepas dan terhindar dari infeksi. Sebagai upaya untuk meminimalkan berkembangnya infeksi tali pusat yaitu dengan menjaga tali pusat tetap bersih dan kering. Perawatan tali pusat merupakan tindakan yang bertujuan merawat tali pusat pada bayi baru lahir agar tetap kering dan mencega terjadinya infeksi.

Cara pelepasan tali pusat dapat dengan menggunakan metode topikal ASI, alkohol, betadine, dan kassa kering steril (Ernila, 2016). Alasan dari pada merawat tali pusat dengan baik dan sesuai standar yaitu menggunakan kassa kering steril adalah untuk menjaga agar tali pusat tetap kering dan bersih. Merawat tali pusat menggunakan kassa kering steril dapat menjadikan tali pusat tetap kering dan bersih, sehingga dapat mengurangi resiko terjadinya infeksi yang dapat berpengaruh pada lama pelepasan tali pusat pada bayi baru lahir (Sastrawinata, 2011).

Perawatan tali pusat yang tidak sesuai standar kesehatan dapat mengakibatkan berbagai gangguan kesehatan pada bayi, di antaranya tetanus neonatorum, omfalitis atau infeksi tali pusat, dan perdarahan tali pusat. Berikut ini dampak dari perawatan tali pusat tidak steril. Menurut Sodikin (2013), sebagai berikut: Omfalitis atau infeksi tali pusat. Penyebab infeksi tali pusat ini dalah bakteri stapilokokus, streptokokus, atau bakteri lainnya.

Waktu pelepasan tali pusat dipengaruhi oleh cara perawatan tali pusat, kelembaban tali pusat, kondisi sanitasi lingkungan sekitar neonatus, dan timbulnya infeksi pada tali pusat karena tindakan atau perawatan yang tidak memenuhi syarat kebersihan atau tidak sesuai dengan standar yang telah ditentukan. Dampak 
perawatan tali pusat yang salah dapat mengakibatkan waktu pelepasan tali pusat semakin lama dan infeksi tali pusat. Infeksi pada tali pusat dapat menyebabkan sepsis, meningitis, dan lain-lain (Sodikin, 2013).

Beberapa penelitian menunjukkan bahwa lama pelepasan pelepasan tali pusat pada bayi dengan kasa kering lebih cepat dibandingkan dengan kasa alkohol 70\%. Tali pusat akan terlepas dengan sendirinya, sehinggga sangat tidak dianjurkan untuk memegang atau menarik-narik tali pusat (Ronald,2011).

Menurut Sodikin (2013), pelepasan tali pusat memiliki rentan waktu sebagai berikut: Cepat $<5$ hari tali pusat telah puput, Normal 57 hari tali pusat telah puput dan Lambat $>7$ hari tali pusat puput, Banyak faktor yang dapat mempengaruhi puputnya tali pusat di antaranya adalah perawatan tali pusat yang tidak benar dan sesuai petunjuk medis yang dapat mengakibatkan infeksi tali pusat, tetanatus neonatorum, dan perdarahan tali pusat yang berujung pada lama pelepasan tali pusat.

Menurut IDAI (2011), prinsip perawatan tali pusat adalah sebagai berikut: Jangan mengoleskan bahan atau ramuan apapun ke puntung tali pusat dan hal-hal berikut perlu menjadi perhatian ibu dan keluarga: Memperhatikan popok di area puntung tali pusat, Jika puntung tali pusat kotor, cuci secara hati-hati dengan air dan sabun. keringkan secara seksama dengan kain bersih atau kassa steril dan Jika pusat menjadi merah atau mengeluarkan nanah atau darah, harus segara bawa bayi tersebut ke fasilitas yang mampu memberikan perawatan tali pusat secara lengkap.

Berdasarkan analisis bivariate diketahui bahwa hasil uji hipotesa chi square diperoleh pvalue sebesar 0,022, maka dapat disimpulkan bahwa ada hubungan perawatan tali pusat menggunakan kassa kering steril sesuai standar terhadap lamanya pelepasan tali pusat bayi di Puskesmas Siantan Hilir tahun 2019. Perawatan tali pusat pada prinsipnya menjaga agar kondisi tali pusat tetap kering, tidak lembab dan bersih. Oleh karena itu dianjurkan untuk tidak memberikan bahan apapun pada tali pusat, cukup membersihkan dan membalut dengan kasa kering steril.

Kassa steril adalah kain yang bebas dari kuman-kuman penyakit. Kassa steril adalah kain kasa dengan kemasan punch satuan yang berkualitas tinggi. Perawatan tali pusat pada bayi baru lahir dengan menggunakan kassa kering steril sesuai dengan SOP yang di tentukan sangat efektif dalam proses pelepasan tali pusat, Dimana tali pusat akan menjadi cepat kering, dan tetap membuat tali pusat tetap bersih sepanjang hari, sehingga tali pusat pada bayi baru lahir akan terlepas dengan normal tanpa ada efek samping yang ditimbulkan.

Penelitian ini sejalan dengan dilakukan oleh Puji, Astutik tahun 2016. Hasil penelitian menunjukkan bahwa seluruh (100\%) responden 24 mengalami pelepasan tali pusat secara normal (5-7 hari) setelah dilakukan perawatan tali pusat menggunakan kassa kering steril. Seluruh responden (100\%) mengalami pelepasan tali pusat secara lambat (>7 hari) setelah dilakukan perawatan tali pusat 
menggunakan kassa alkohol 70\%. Hasil uji

Man Whitney diperoleh $p$-value $=0,000 \leq \alpha=$ 0,05 sehingga $\mathrm{Ha}$ diterima dan $\mathrm{H}_{0}$ ditolak. Ada pengaruh perawatan tali pusat dengan menggunakan kassa kering steril terhadap pelepasan tali pusat pada bayi baru lahir di wilayah kerja Puskesmas Sumbersari Saradan Kabupaten Madiun.

\section{Kesimpulan}

Berdasarkan hasil penelitian diatas bahwa penggunaan kassa kering steril sangat efektif untuk merawat tali pusat bayi baru lahir dan dilihat dari segi lama pelepasan tali pusat jauh lebih efektif dalam proses pelepasan tali pusat yang masuk dalam kategori normal. Saran kepada pihak puskesmas untuk tetap memberikan informasi tentang perawatan tali pusat sesuai standar yaitu dengan kassa kering steril karena dapat dilihat dari hasil penelitian bahwa kassa kering steril sesuai standar efektif untuk melakukan perawatan tali pusat.

Saran kepada pihak puskesmas untuk tetap memberikan informasi tentang perawatan tali pusat sesuai standar yaitu dengan kassa kering steril karena dapat dilihat dari hasil penelitian bahwa kassa kering steril sesuai standar efektif untuk melakukan perawatan tali pusat.

\section{Daftar Pustaka}

Asiyah,Nor. 2017. Perawatan Tali Pusat Terbuka Sebagai Upaya Mempercepat Pelepasan Tali Pusat Pada Bayi Baru Lahir

Astutik, Puji. 2016. Perawatan tali pusat dengan teknik Kasa Kering Steril dan Kasa
Alkohol $70 \%$ terhadap pelepasan Tali pusat pada Bayi Baru Lahir di Wilayah Kerja Puskemas Sumber Sari Saradan Kabupaten Madiun

Depkes, RI. 2010. Asuhan Persalinan Normal. Jakarta: Depkes RI.

Dinkes Kalbar. 2017. Angka Kematian Bayi. Kalimantan Barat: Dinkes Pontianak.

Ellen, Pesak. 2014. Hubungan Pengetahuan Ibu Dengan Pemberian Tetanus Toxoid di Puskesmas Rurukan Kecamatan Tomohon

Ernila, K. 2016. Perawatan Tali Pusat. Jakarta: EGC.

Hartono,Aris. 2015. Efektifitas Penggunaaan Alkohol 70\% dan Kasa Kering Pada Percepatan Pelepasan Tali Pusat Bayi. STIKES Dian Husada Mojokerto.

Hidayat. 2011. Ilmu Kesehatan Anak Untuk Pendidikan Kebidanan. Jakarta: Salamba Medika.

Ikatan Dokter Anak Indonesia (IDAI).2011. Buku Ajar Respirologi Anak, Edisi Pertama.Jakarta: Badan Penerbit Ikatan Dokter Anak Indonesia

Kasiati. 2015. Model Asuhan Keperawatan Tali Pusat Pada Bayi di RS. Kasih Bunda Surabaya.

Paisal. 2013. Perawatan Bayi Baru Lahirl. Yogyakarta: Graha Medika

Ronald. 2011. Tali Pusat dan Plasenta Bayi.Jakarta: Dunia Sehat

Saifuddin. 2014. Panduan Praktis Pelayanan Maternal Dan Neonatal. Jakarta: EGC.

Sastrawinata, P. 2011. Buku saku perawatan tali pusat. Jakarta: EGC.

Sodikin. 2013. Buku Saku Perawatan Tali Pusat.Jakarta:EGC

Wibowo, Nuroyono. 2013. Plasenta, Tali Pusat, Selaput Janin dan Cairan Amnion. Jakarta: Balai Penerbit FKUI 
Volume 9 Nomor 1 Tahun 2019

Wiknjosastro. 2011. Ilmu Kebidanan. Jakarta:

Bina Pustaka Sarwono Prawirahardjo.

World Health Organization (WHO). 2016. Angka Kematian Bayi. WHO 